Prepared in cooperation with the Triangle Area Water Supply Monitoring Project Steering Committee

\title{
Triangle Area Water Supply Monitoring Project, North Carolina-Summary of Monitoring Activities, Quality Assurance, and Data, October 2013-September 2015
}

Open-File Report 2017-1068 
Cover. B. Everett Jordan Lake above U.S. Highway 64 at Wilsonville, North Carolina (U.S. Geological Survey streamgaging station 0209799150). Photograph by Ryan B. Rasmussen, USGS. 


\section{Triangle Area Water Supply Monitoring Project, North Carolina-Summary of Monitoring Activities, Quality Assurance, and Data, October 2013-September 2015}

By C.A. Pfeifle, J.L. Cain, and R.B. Rasmussen

Prepared in cooperation with the Triangle Area Water Supply Monitoring Project Steering Committee

Open-File Report 2017-1068 


\title{
U.S. Department of the Interior \\ RYAN K. ZINKE, Secretary
}

\section{U.S. Geological Survey William H. Werkheiser, Acting Director}

\author{
U.S. Geological Survey, Reston, Virginia: 2017
}

For more information on the USGS - the Federal source for science about the Earth, its natural and living resources, natural hazards, and the environment-visit https://www.usgs.gov or call 1-888-ASK-USGS.

For an overview of USGS information products, including maps, imagery, and publications,

visit https://store.usgs.gov/.

Any use of trade, firm, or product names is for descriptive purposes only and does not imply endorsement by the U.S. Government.

Although this information product, for the most part, is in the public domain, it also may contain copyrighted materials as noted in the text. Permission to reproduce copyrighted items must be secured from the copyright owner.

Suggested citation:

Pfeifle, C.A., Cain, J.L., and Rasmussen, R.B., 2017, Triangle Area Water Supply Monitoring Project, North CarolinaSummary of monitoring activities, quality assurance, and data, October 2013-September 2015: U.S. Geological Survey Open-File Report 2017-1068, 13 p., 1 table, 3 appendix files, https://doi.org/10.3133/ofr20171068.

ISSN 2331-1258 (online) 


\section{Contents}

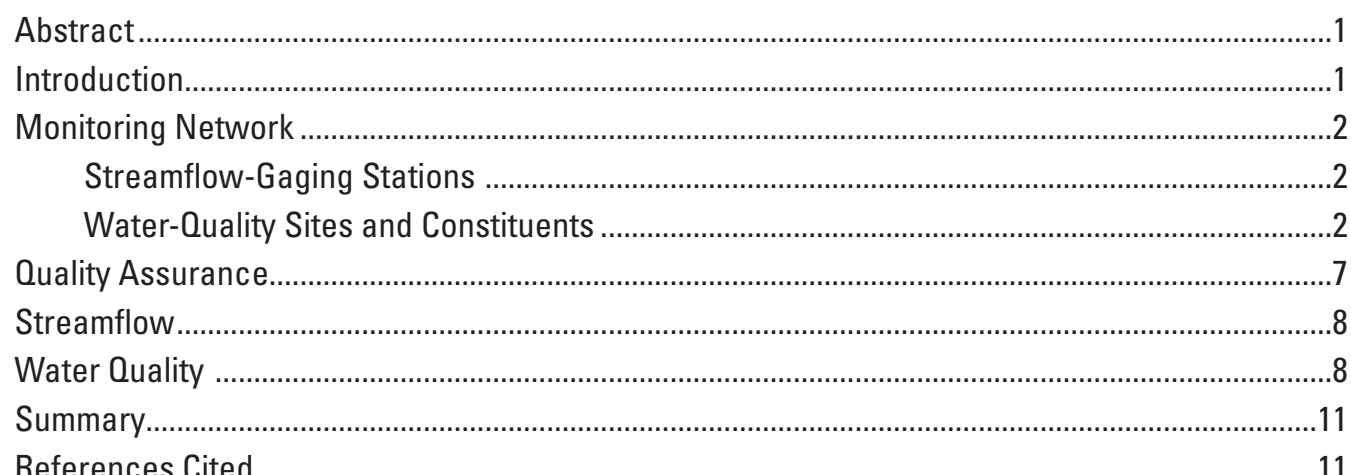

\section{Figures}

1. Map showing location of Triangle Area Water Supply Monitoring Project data-collection sites in the upper Cape Fear and Neuse River Basins, North Carolina, October 2013 through September 2015

2. Graphs showing annual runoff measured from October 2013 through September 2014 and October 2014 through September 2015, and the long-term mean runoff for the period of record at 10 streamflow-gaging stations in the Triangle area of North Carolina

3. Maps showing sites in the Triangle area of North Carolina with one or more measurement of dissolved-oxygen concentration less than 5 milligrams per liter, dissolved-oxygen percent saturation values greater than 110 percent, $\mathrm{pH}$ values greater than 9 standard units, turbidity values greater than 25 nephelometric turbidity units for lakes and reservoirs or greater than 50 nephelometric turbidity units for streams, and concentrations of chlorophyll a greater than 40 micrograms per liter, October 2013 through September 2015.

\section{Tables}

1. Water-quality and streamflow monitoring sites for the Triangle Area Water Supply Monitoring Project, October 2013 through September 2015

2. Physical properties measured in the field and chemical constituents analyzed at the National Water Quality Laboratory for the Triangle Area Water Supply Monitoring Project, and the methods used for analyses, October 2013 through September 2015.

3. Summary of selected constituent data observed in vehicle and field blanks and environmental samples from the Triangle Area Water Supply Monitoring Project, October 2013 through September 2015 


\section{Digital Data in Excel Format}

[Available for downloading from https://doi.org/10.3133/ofr20171068]

Table 4. Summary of water-quality results for sampled sites in the Triangle Area Water Supply Monitoring Project, October 2013 through September 2015.

Appendix 1. Water-quality data for surface-water samples collected from October 2013 through September 2015 at the Triangle Area Water Supply Monitoring Project study sites, North Carolina

Appendix 2. Analytical results for blanks collected during surface-water sampling at the Triangle Area Water Supply Monitoring Project study sites, North Carolina, October 2013 through September 2015

Appendix 3. Analytical results for the environmental and replicate sample sets collected October 2013 through September 2015 at the Triangle Area Water Supply Monitoring Project study sites, North Carolina 


\section{Conversion Factors}

U.S. customary units to International System of Units

\begin{tabular}{|c|c|c|}
\hline Multiply & By & To obtain \\
\hline \multicolumn{3}{|c|}{ Length } \\
\hline inch (in.) & 25.4 & millimeter (mm) \\
\hline mile (mi) & 1.609 & kilometer $(\mathrm{km})$ \\
\hline \multicolumn{3}{|c|}{ Flow rate } \\
\hline cubic foot per second $\left(\mathrm{ft}^{3} / \mathrm{s}\right)$ & 0.02832 & cubic meter per second $\left(\mathrm{m}^{3} / \mathrm{s}\right)$ \\
\hline
\end{tabular}

Temperature in degrees Celsius $\left({ }^{\circ} \mathrm{C}\right)$ may be converted to degrees Fahrenheit $\left({ }^{\circ} \mathrm{F}\right)$ as follows:

$$
{ }^{\circ} \mathrm{F}=\left(1.8 \times{ }^{\circ} \mathrm{C}\right)+32 .
$$

\section{Supplemental Information}

Water year is defined as the period from October 1 to September 30 and is identified by the year in which the period ends. For example, water year 2014 is October 1, 2013, to September 30, 2014.

Specific conductance is given in microsiemens per centimeter at 25 degrees Celsius $\left(\mu \mathrm{S} / \mathrm{cm}\right.$ at $\left.25^{\circ} \mathrm{C}\right)$.

Concentrations of chemical constituents in water are given in either milligrams per liter (mg/L) or micrograms per liter $(\mu \mathrm{g} / \mathrm{L})$.

\section{Abbreviations}

$\begin{array}{ll}\text { MCL } & \text { maximum contaminant level } \\ \text { NCDEO } & \text { North Carolina Department of Environmental Quality } \\ \text { NCDWR } & \text { North Carolina Division of Water Resources } \\ \text { NWISWeb } & \text { USGS National Water Information System } \\ \text { RPD } & \text { relative percent difference } \\ \text { SDWR } & \text { secondary drinking-water regulation } \\ \text { TAWSMP } & \text { Triangle Area Water Supply Monitoring Project } \\ \text { USGS } & \text { U.S. Geological Survey }\end{array}$





\title{
Triangle Area Water Supply Monitoring Project, North Carolina-Summary of Monitoring Activities, Quality Assurance, and Data, October 2013-September 2015
}

\author{
By C.A. Pfeifle, J.L. Cain, and R.B. Rasmussen
}

\section{Abstract}

Surface-water supplies are important sources of drinking water for residents in the Triangle area of North Carolina, which is located within the upper Cape Fear and Neuse River Basins. Since 1988, the U.S. Geological Survey and a consortium of local governments have tracked water-quality conditions and trends in several of the area's water-supply lakes and streams. This report summarizes data collected through this cooperative effort, known as the Triangle Area Water Supply Monitoring Project, during October 2013 through September 2014 (water year 2014) and October 2014 through September 2015 (water year 2015). Major findings for this period include:

- More than 5,500 individual measurements of water quality were made at a total of 15 sites - 4 in the Neuse River Basin and 11 in the Cape Fear River Basin. Thirty water-quality properties or constituents were measured; State water-quality thresholds exist for 11 of these.

- All observations met State water-quality thresholds for temperature, hardness, chloride, fluoride, sulfate, and nitrate plus nitrite.

- North Carolina water-quality thresholds were exceeded one or more times for dissolved oxygen, dissolved-oxygen percent saturation, $\mathrm{pH}$, turbidity, and chlorophyll $a$.

\section{Introduction}

The Triangle area, located within the upper Cape Fear and Neuse River Basins, is one of the most rapidly developing areas of North Carolina. Population growth continues to increase demands for water from public suppliers, the majority of which draw water from streams and lakes in the region. Growth also brings the threat of greater loads of pollutants and new contaminant sources which, if not properly managed, could adversely affect water quality.

For more than 25 years, the Triangle Area Water Supply Monitoring Project (TAWSMP) has tracked water-quality conditions and long-term trends in many of the area's watersupply lakes, rivers, and tributaries. The project has progressed in phases, allowing for flexibility in the monitoring network and partners and for timely response to emerging water-quality concerns (https://nc.water.usgs.gov/projects/triangle/overview. html). Objectives of the project for water years 2014 and 2015 were to

- Extend the existing water-quality database for nutrients, sediment, major ions, and selected metals to track spatial variations in water quality, loads to reservoirs, and long-term water-quality trends.

- Continue monitoring at tributary sites during highflow events to increase the understanding of constituent concentrations and loads during extreme hydrologic conditions.

- Maintain a network of 10 continuous streamflowgaging stations in the study area.

Pursuant to an agreement with several local governments, the U.S. Geological Survey (USGS) monitors hydrologic conditions and collects water-quality samples. One site in the Triangle area consists only of a streamflow gage. Continuous streamflow is recorded at almost all of the stream sites and is funded through the TAWSMP and other USGS programs. The USGS is responsible for data quality assurance, analysis, and interpretation, providing the data to the public and maintaining the data in perpetuity. Funding for the project is provided by local government partners (see sidebar) and by the USGS cooperative matching funds (https://water.usgs.gov/coop/). The Triangle J Council of Governments provides organizational support services for the TAWSMP.

This report summarizes monitoring activities and data collected by the USGS for the TAWSMP during October 2013 through September 2015, also referred to as water years 2014 (October 2013 to September 2014) and 2015 (October 2014 to 


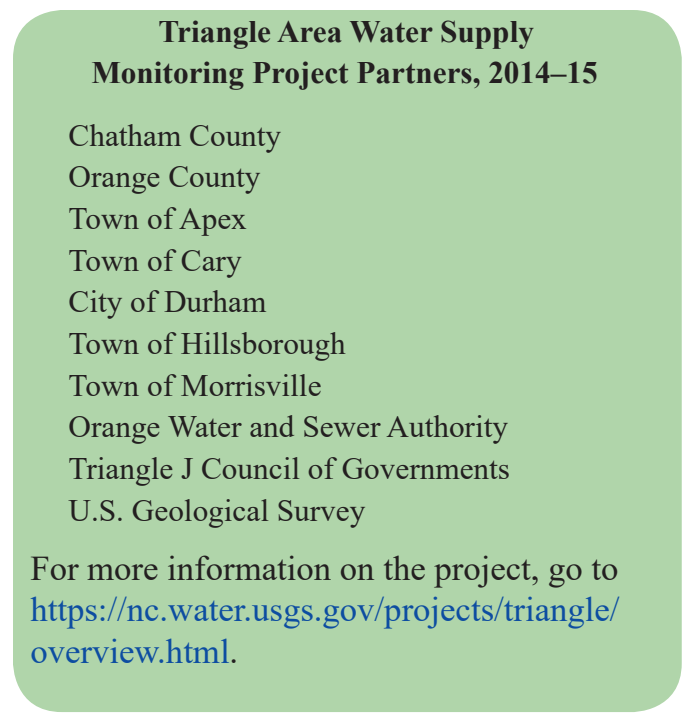

September 2015). Hydrologic conditions in the Triangle area are described. Ranges of concentrations for water-quality field parameters, major ions, nutrients, unfiltered iron and manganese, organic carbon, chlorophyll $a$, and suspended sediment are presented for each site sampled during this period. The supporting data for this report are available at Cain and others (2017; https://doi.org/10.5066/F75X274X).

\section{Monitoring Network}

Since the project began in 1988, several adjustments have been made to sampling locations, sampling frequency, and constituents that are sampled. During 2014-15, the TAWSMP monitoring network was composed of 22 sites, including streamflow-gaging stations and stream and lake water-quality sampling sites (fig. 1). Water-quality samples were collected at 15 sites during this period.

Because of changes in the scope of the project, Little River Reservoir (site 5) and Lake Michie (site 7) were suspended from the sampling rotation after June 2014. Beginning with water year 2015, the sampling frequency for Jordan Lake, Haw River arm (site 11) was reduced from every other month to sampling only during October, April, June, and August. Analyses were discontinued at all lake and stream sites after October 2014 for several unfiltered metals and trace elements (aluminum, arsenic, cadmium, chromium, cobalt, copper, zinc, lead, mercury, molybdenum, nickel, selenium, and silver). Therefore, metals and trace elements data for water years 2014 and 2015 were not summarized in this report. In addition, analysis of unfiltered iron and unfiltered manganese was discontinued at all stream sites after October 2014, although iron and manganese continued to be monitored at lake sites. The data collected as part of this project are available to project partners and the public through the USGS National Water Information System (NWISWeb) database (U.S. Geological Survey, 2017; https://doi.org/10.5066/
F7P55KJN), Cain and others (2017; https://doi.org/10.5066/ F75X274X), or by request from the USGS South Atlantic Water Science Center (https://www.usgs.gov/water/ southatlantic/). Project sampling and analytical methods and quality-assurance practices are described by Oblinger (2004).

\section{Streamflow-Gaging Stations}

Streamflow records are useful for managing water supplies and are essential for determining instream loads of sediment, nutrients, and other constituents and interpreting water-quality trends. The USGS operates 10 continuous-record streamflowgaging stations that are funded through the TAWSMP (table 1). These gages record water level and discharge at 15-minute intervals and display them in near-real time through the USGS NWISWeb database (U.S. Geological Survey, 2017; https://doi.org/10.5066/F7P55KJN). Precipitation and streamflow data for additional sites in the study area are available through other USGS programs (table 1).

\section{Water-Quality Sites and Constituents}

Water-quality data are used to track current conditions and to analyze long-term water-quality trends and pollutant loads in the Triangle area. The USGS monitored water quality at 15 sites in the TAWSMP study area during water years 2014 and 2015. More than 5,500 individual measurements of water quality were made, not including lake vertical-profile measurements. The analytical methods used to measure the physical properties and chemical constituents analyzed for this project are presented in table 2. Measurements were made at 4 sites in the Neuse River Basin and 11 sites in the Cape Fear River Basin. Water-quality data are provided in appendix 1 and are available to project partners and the public by Cain and others (2017; https://doi.org/10.5066/F75X274X) or by request from the USGS South Atlantic Water Science Center (https://www.usgs.gov/water/southatlantic/).

Nine sites at six public water-supply lakes were sampled including West Fork Eno River Reservoir (site 1), Little River Reservoir (site 5), and Lake Michie (site 7) in the Neuse River Basin, and Cane Creek Reservoir (site 9), University Lake (site 15), and Jordan Lake (sites 11, 18, 20, 21) in the Cape Fear River Basin (table 1; fig. 1). Jordan Lake is a large, multipurpose reservoir managed by the U.S. Army Corps of Engineers. Four sites in Jordan Lake were sampled bimonthly during water years 2014 and 2015 except for Jordan Lake, Haw River arm (site 11), as previously mentioned, at which sampling was reduced to four times per year beginning in water year 2015. The five smaller reservoirs are used primarily for water supplies although most also provide recreational access. One site in each of the smaller lakes was sampled four times (October, April, June, and August) per year.

Lake samples were collected at multiple depths, but only near-surface samples are summarized in this report. Vertical profiles of field parameters (water temperature, dissolved 


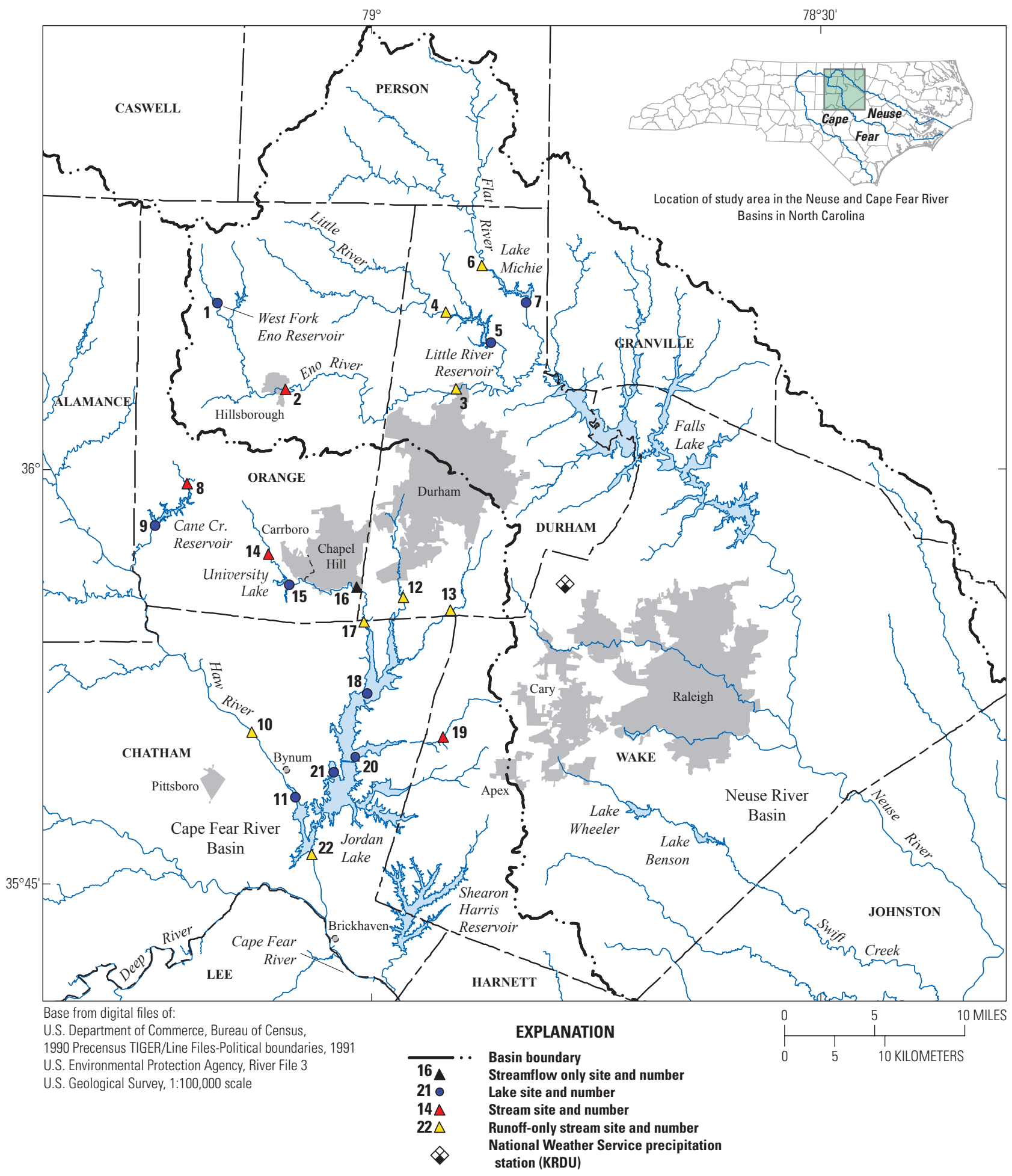

Figure 1. Map showing location of Triangle Area Water Supply Monitoring Project data-collection sites in the upper Cape Fear and Neuse River Basins, North Carolina, October 2013 through September 2015. 
Table 1. Water-quality and streamflow monitoring sites for the Triangle Area Water Supply Monitoring Project, October 2013 through September 2015.

[USGS, U.S. Geological Survey; Lake, lake sites that were sampled bimonthly; Stream (routine), stream sites that were sampled bimonthly and during runoff; Stream (runoff), stream sites that were sampled only during runoff events; n/a, not applicable for lake sites; --, data were not collected (refer to footnote); SR, Secondary Road; USACE, U.S. Army Corps of Engineers]

\begin{tabular}{|c|c|c|c|c|c|}
\hline \multirow[b]{2}{*}{ Map no. (fig. 1) } & \multirow[b]{2}{*}{$\begin{array}{l}\text { Site location in North Carolina and USGS } \\
\text { station number (in downstream order) }\end{array}$} & \multicolumn{4}{|c|}{ Data collected during October 2013-September 2015} \\
\hline & & Site type & $\begin{array}{l}\text { Water } \\
\text { quality }\end{array}$ & $\begin{array}{l}\text { Continuous } \\
\text { streamflow }\end{array}$ & $\begin{array}{l}\text { Period of record } \\
\text { for continuous } \\
\text { streamflow sites }\end{array}$ \\
\hline \multicolumn{6}{|c|}{ Neuse River Basin } \\
\hline 1 & $\begin{array}{l}\text { West Fork Eno River Reservoir at dam near Cedar } \\
\text { Grove, } 0208480275\end{array}$ & Lake & Yes & $\mathrm{n} / \mathrm{a}$ & $\mathrm{n} / \mathrm{a}$ \\
\hline 3 & Eno River near Durham, 02085070 & Stream (runoff) & No & Yes & $1963-2015$ \\
\hline 4 & $\begin{array}{l}\text { Little River at SR } 1461 \text { near Orange Factory, } \\
0208521324\end{array}$ & Stream (runoff) & No & Yes & $1987-2015$ \\
\hline 5 & $\begin{array}{l}\text { Little River Reservoir at dam near Bahama, } \\
0208524845\end{array}$ & Lake & Yes & $\mathrm{n} / \mathrm{a}$ & $\mathrm{n} / \mathrm{a}$ \\
\hline 8 & Cane Creek near Orange Grove, 02096846 & Stream (routine) & Yes & Yes & $1989-2015$ \\
\hline 9 & $\begin{array}{l}\text { Cane Creek Reservoir at dam near White Cross, } \\
0209684980\end{array}$ & Lake & Yes & $\mathrm{n} / \mathrm{a}$ & $\mathrm{n} / \mathrm{a}$ \\
\hline 10 & Haw River near Bynum, 02096960 & Stream (runoff) & No & $(\mathrm{USACE})^{1}$ & $1973-2015$ \\
\hline 11 & $\begin{array}{l}\text { B. Everett Jordan Lake, Haw River arm near } \\
\text { Hanks Chapel, } 0209699999\end{array}$ & Lake & Yes & $\mathrm{n} / \mathrm{a}$ & $\mathrm{n} / \mathrm{a}$ \\
\hline 12 & New Hope Creek near Blands, 02097314 & Stream (runoff) & Yes & Yes & $1983-2015$ \\
\hline 13 & $\begin{array}{l}\text { Northeast Creek at SR } 1100 \text { near Genlee, } \\
0209741955\end{array}$ & Stream (runoff) & Yes & Yes & $1983-2015$ \\
\hline 14 & Morgan Creek near White Cross, 02097464 & Stream (routine) & Yes & Yes & $1989-2015$ \\
\hline 19 & $\begin{array}{l}\text { White Oak Creek at mouth near Green Level, } \\
0209782609\end{array}$ & Stream (routine) & Yes & Yes & $2000-2015$ \\
\hline 20 & $\begin{array}{l}\text { B. Everett Jordan Lake above U.S. Highway } 64 \text { at } \\
\text { Wilsonville, } 0209799150\end{array}$ & Lake & Yes & $\mathrm{n} / \mathrm{a}$ & $\mathrm{n} / \mathrm{a}$ \\
\hline 21 & $\begin{array}{l}\text { B. Everett Jordan Lake at Bells Landing near Grif- } \\
\text { fins Crossroads, } 0209801100\end{array}$ & Lake & Yes & $\mathrm{n} / \mathrm{a}$ & $\mathrm{n} / \mathrm{a}$ \\
\hline 22 & $\begin{array}{l}\text { Haw River below B. Everett Jordan Lake dam near } \\
\text { Moncure, } 02098198\end{array}$ & Stream (runoff) & No & $--^{3}$ & $1966-2015$ \\
\hline
\end{tabular}

\footnotetext{
${ }^{1}$ Gage funded through separate agreement with the U.S. Army Corps of Engineers.
}

${ }^{2}$ Streamflow from nearby gage, USGS station 02097517.

${ }^{3}$ Streamflow computed from USACE releases from the Jordan Lake dam. 
Table 2. Physical properties measured in the field and chemical constituents analyzed at the National Water Quality Laboratory (NWOL) for the Triangle Area Water Supply Monitoring Project, and the methods used for analyses, 0ctober 2013 through September 2015.

$\left[{ }^{\circ} \mathrm{C}\right.$, degree Celsius; USGS, U.S. Geological Survey; m, meter; $\mu \mathrm{S} / \mathrm{cm}$ at $25{ }^{\circ} \mathrm{C}$, microsiemens per centimeter at 25 degrees Celsius; mg/L, milligram per liter; ASTM, American Society for Testing and Materials; $\mathrm{pH}$, negative log (base 10) of the hydrogen ion activity; $\mathrm{CaCO}_{3}$, calcium carbonate; $\mathrm{N}$, nitrogen; P, phosphorus; EPA, U.S. Environmental Protection Agency; $\mathrm{SiO}_{2}$, silicon dioxide; $\mu \mathrm{g} / \mathrm{L}$, microgram per liter; DA, (automated) discrete analyzer; ASF, automated segmented flow]

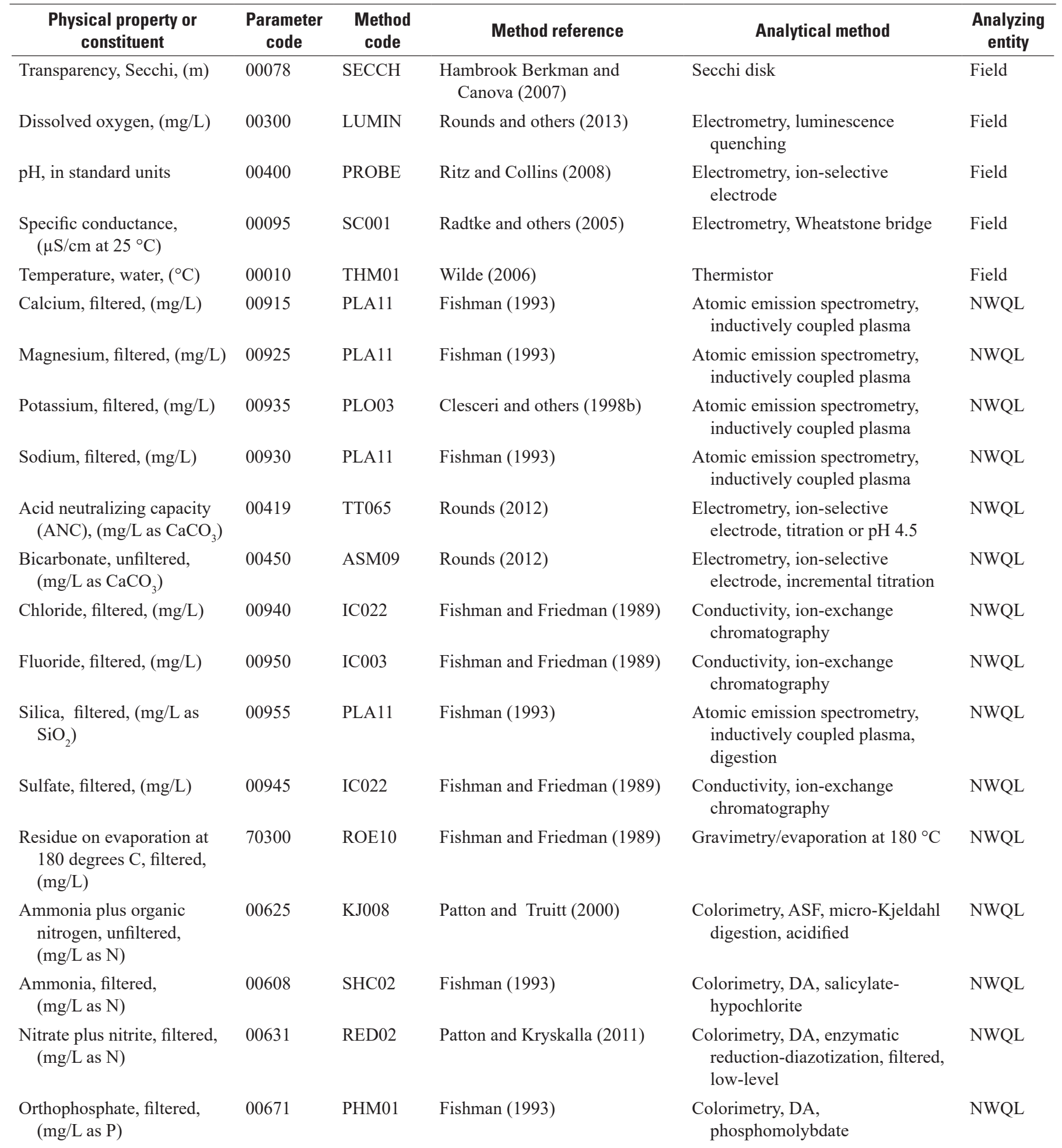


Table 2. Physical properties measured in the field and chemical constituents analyzed at the National Water Quality Laboratory (NWOL) for the Triangle Area Water Supply Monitoring Project, and the methods used for analyses, October 2013 through September 2015.-Continued

$\left[{ }^{\circ} \mathrm{C}\right.$, degree Celsius; USGS, U.S. Geological Survey; m, meter; $\mu \mathrm{S} / \mathrm{cm}$ at $25{ }^{\circ} \mathrm{C}$, microsiemens per centimeter at 25 degrees Celsius; $\mathrm{mg} / \mathrm{L}$, milligram per liter; ASTM, American Society for Testing and Materials; $\mathrm{pH}$, negative log (base 10) of the hydrogen ion activity; $\mathrm{CaCO}_{3}$, calcium carbonate; $\mathrm{N}$, nitrogen; P, phosphorus; EPA, U.S. Environmental Protection Agency; $\mathrm{SiO}_{2}$, silicon dioxide; $\mu \mathrm{g} / \mathrm{L}$, microgram per liter; DA, (automated) discrete analyzer; ASF, automated segmented flow]

\begin{tabular}{|c|c|c|c|c|c|}
\hline $\begin{array}{l}\text { Physical property or } \\
\text { constituent }\end{array}$ & $\begin{array}{l}\text { Parameter } \\
\text { code }\end{array}$ & $\begin{array}{l}\text { Method } \\
\text { code }\end{array}$ & Method reference & Analytical method & $\begin{array}{l}\text { Analyzing } \\
\text { entity }\end{array}$ \\
\hline $\begin{array}{l}\text { Phosphorus, unfiltered, } \\
\text { (mg/L as P) }\end{array}$ & 00665 & CL021 & EPA (1993) & $\begin{array}{l}\text { Colorimetry, ASF, alkaline- } \\
\text { persulfate digestion, low level }\end{array}$ & NWQL \\
\hline $\begin{array}{l}\text { Total organic carbon, } \\
\text { unfiltered, }(\mathrm{mg} / \mathrm{L})\end{array}$ & 00680 & COMB9 & Clesceri and others (1998a) & $\begin{array}{l}\text { Non-dispersive infrared analysis, } \\
\text { high temperature combustion }\end{array}$ & NWQL \\
\hline $\begin{array}{l}\text { Iron, unfiltered, recoverable, } \\
\quad(\mu \mathrm{g} / \mathrm{L})\end{array}$ & 01045 & PLA15 & Garbarino and Struzeski (1998) & $\begin{array}{l}\text { Atomic emission spectrometry, } \\
\text { inductively coupled plasma, } \\
\text { digestion }\end{array}$ & NWQL \\
\hline \multirow[t]{2}{*}{$\begin{array}{l}\text { Manganese, unfiltered, } \\
\text { recoverable, }(\mu \mathrm{g} / \mathrm{L})\end{array}$} & 01055 & PLA15 & Garbarino and Struzeski (1998) & $\begin{array}{l}\text { Mass spectrometry, inductively } \\
\text { coupled plasma, digestion }\end{array}$ & NWQL \\
\hline & & PLM48 & Garbarino and Struzeski (1998) & $\begin{array}{l}\text { Mass spectrometry, inductively } \\
\text { coupled plasma, digestion }\end{array}$ & NWQL \\
\hline
\end{tabular}

oxygen, specific conductance, and $\mathrm{pH}$ ) were measured at 1-meter (m) depth intervals at the sampling location, along with water transparency, which was measured by Secchi disk. Water samples were collected for analysis of acid neutralizing capacity, turbidity, nutrients (ammonia plus organic nitrogen, ammonia, nitrate plus nitrite, orthophosphate, and phosphorus), major ions (calcium, magnesium, sodium, potassium, chloride, fluoride, sulfate, and silica), unfiltered iron and manganese, total organic carbon, phytoplankton, and chlorophyll $a$ during each sampling trip (Oblinger, 2004). Study results for turbidity are in nephelometric turbidity ratio units (NTRU), which are not significantly different from nephelometric turbidity units (NTU). In this report, ammonia plus organic nitrogen, ammonia, and nitrate plus nitrite are reported in milligrams per liter as nitrogen ( $\mathrm{mg} / \mathrm{L}$ as $\mathrm{N})$, and orthophosphate and phosphorus are reported in milligrams per liter as phosphorus ( $\mathrm{mg} / \mathrm{L}$ as $\mathrm{P})$.

Four stream sites were sampled by the USGS on a bimonthly basis to measure field properties, nutrients, major ions, total organic carbon, and suspended sediment. These sites include Eno River at Hillsborough (site 2), Cane Creek near Orange Grove (site 8), Morgan Creek near White Cross (site 14), and White Oak Creek (site 19, fig. 1; table 1). Samples were collected at multiple locations along a transect and were composited. Sampling was not conducted during zero-flow conditions, which occasionally occurs at the smaller streams. In addition to bimonthly sampling at the four stream sites, an additional eight stream sites in the TAWSMP network were considered for sampling only during storm-runoff events when water levels were rapidly increasing because of localized rainfall events. During 2014-15, two additional stream sites were sampled by the USGS during selected storm-runoff events, including New Hope Creek near Blands (site 12) and Northeast Creek at Secondary Road 1100 near Genlee (site 13). These higher-flow samples supplement fixed-interval data collected by the North Carolina Division of Water Resources (NCDWR) as part of the Ambient Monitoring System (http://deq.nc.gov/ about/divisions/water-resources/water-resources-data/watersciences-home-page/ecosystems-branch/ambient-monitoringsystem). It is important to note that results for the two streams sampled only during runoff events likely do not represent typical water-quality conditions for these streams.

Acid neutralizing capacity was determined in the field at the time of sampling, using USGS standard methods (Rounds, 2012). Nutrient and major ions analyses were performed at the USGS National Water Quality Laboratory (NWQL) in Denver, Colorado. Chlorophyll $a$ analyses were performed by Meritech, Inc., in Reidsville, N.C. Meritech, Inc., participated in the chlorophyll $a$ interlaboratory performance comparisons (round robins) sponsored by the NCDWR during 2014 and 2015. Water samples were analyzed for suspended sediment concentrations at the USGS Eastern Region Sediment Laboratory in Louisville, Kentucky.

During water years 2014 and 2015, routine sampling at the nine lake sites and the four bimonthly stream sites was conducted on schedule with a few exceptions. Little River Reservoir (site 5), Lake Michie (site 7), Jordan Lake, Haw River arm (site 11), Jordan Lake at buoy 12 (site 18), Jordan Lake at U.S. Highway 64 (site 20), and Jordan Lake at Bells Landing (site 21) were sampled during May rather than April 2014. Morgan Creek near White Cross (site 14) and White Oak Creek (site 19) were sampled in March instead of February 2015. 


\section{Quality Assurance}

Quality-control samples, consisting of sampling-vehicle (ambient) blanks, field blanks and replicate samples, were collected and reviewed throughout the period to ensure that project data-quality objectives were met (appendixes 2, 3; Oblinger, 2004). Deionized water was produced in the USGS Raleigh laboratory and was used to clean the sampling equipment. The source solution for sampling-vehicle and field blanks was inorganic-blank or organic-blank water (depending on the constituents to be analyzed) obtained from the USGS National Field Supply Service. Approximately 16 percent of the sample load consisted of quality-control samples. Quality-control samples and collection procedures are described in chapter A4 of the USGS National Field Manual (U.S. Geological Survey, 2006).

Five sampling-vehicle blanks and 14 field blanks were collected and analyzed during October 2013 through September 2015 for major ions, nutrients, trace metals, chlorophyll $a$, and total organic carbon (appendix 2). In all, 17 constituents were analyzed and 212 blank results were generated. Approximately 91 percent of the results were below censoring levels, indicating minimal contamination during this period. Overall, 20 quantified blank results were detected (results above constituent censoring levels), which represents approximately 9 percent of the results. Four of these blank results were low-level detections of ammonia; the remaining 16 detections were distributed among 6 different constituents.

Two vehicle blanks and 11 field blanks had quantified detections of one or more constituents, indicating that contamination would be more likely to occur during field sampling and processing (appendix 2). Even so, the number of detections overall was very low, and most of the detections were at or near constituent censoring levels, indicating negligible systematic positive bias.

A constituent detection rate of less than 10 percent was deemed acceptable for this study. If a constituent was detected in greater than 10 percent of the combined vehicle and field blanks, the results for that constituent were assessed for the potential to positively bias the environmental results. Six constituents exceeded the 10 percent blank-detection threshold, including chloride (36 percent), silica (21 percent), sulfate (14 percent), ammonia (29 percent), phosphorus (21 percent), and iron (29 percent). For these constituents, blank detections were further evaluated on the basis of proximity to censoring levels and relevance to corresponding environmental concentrations. Environmental concentrations less than five times the median of the quantified blank detections generally were considered to have some potential for contamination (table 3). Concentrations of chloride, silica, sulfate, and iron in all environmental samples were higher than the threshold and likely were not biased by contamination; therefore, these constituents were not listed in table 3 .

Concentrations of chloride, silica, sulfate, and iron in all environmental samples were higher than the threshold and likely were not biased by contamination. Ammonia was detected in four field blanks with a median detection concentration of $0.015 \mathrm{mg} / \mathrm{L}$. Therefore, environmental ammonia concentrations greater than or equal to 0.01 and less than $0.075 \mathrm{mg} / \mathrm{L}$ were considered potentially biased due to contamination during field sampling activities. During water years $2014-15$, approximately 55 percent of the ammonia concentrations were within this range and should be interpreted with caution. Ammonia concentrations less than $0.01 \mathrm{mg} / \mathrm{L}$ (censored values) were not considered to be positively biased, because they were reported as nondetections.

Phosphorus was detected in one vehicle blank and two field blanks. The median detection was $0.006 \mathrm{mg} / \mathrm{L}$; therefore, a potential-contamination threshold of $0.03 \mathrm{mg} / \mathrm{L}$ was computed. Concentrations in environmental samples ranged from 0.015 to $0.371 \mathrm{mg} / \mathrm{L}$. Approximately 18 percent had concentrations less than the threshold and may be biased by sampling artifacts.

The variability of sampling and analysis was assessed with 21 sets of field replicates (appendix 3). Among the 21 sets of field replicates, there were a total of 220 replicateresult pairs. Paired concentrations with a relative percent difference (RPD, absolute difference times 100 divided by the average) less than 25 percent were considered to demonstrate acceptable reproducibility. Of the 220 replicate set pairs, approximately 98 percent had RPDs less than 25 percent.

Table 3. Summary of selected constituent data observed in vehicle and field blanks and environmental samples from the Triangle Area Water Supply Monitoring Project, October 2013 through September 2015.

$[\mathrm{N}$, nitrogen; P, phosphorus; <, less than $]$

\begin{tabular}{|c|c|c|c|c|c|c|c|c|c|}
\hline \multirow[b]{3}{*}{ Constituent } & \multirow[b]{3}{*}{ Units } & \multirow[b]{3}{*}{$\begin{array}{l}\text { Censoring } \\
\text { Level }\end{array}$} & \multicolumn{5}{|c|}{ Blanks } & \multicolumn{2}{|c|}{ Environmental samples } \\
\hline & & & \multirow[b]{2}{*}{$\begin{array}{l}\text { Number } \\
\text { of blanks } \\
\text { analyzed }\end{array}$} & \multicolumn{3}{|c|}{ Blanks with detections } & \multirow{2}{*}{$\begin{array}{l}5 \text { times the } \\
\text { median } \\
\text { quantified } \\
\text { detection }\end{array}$} & \multirow{2}{*}{\multicolumn{2}{|c|}{$\begin{array}{l}\text { Percent less } \\
\text { than } 5 \text { times } \\
\text { the median } \\
\text { concentration } \\
\text { detected in a } \\
\text { blank }\end{array}$}} \\
\hline & & & & Number & Percent & $\begin{array}{l}\text { Range of } \\
\text { quantified } \\
\text { detections }\end{array}$ & & & \\
\hline Ammonia, filtered & $\begin{array}{l}\text { milligrams per } \\
\text { liter as } \mathrm{N}\end{array}$ & 0.01 & 14 & 4 & 28.6 & $0.01-0.05$ & 0.08 & $<0.01-0.31$ & 55.0 \\
\hline $\begin{array}{r}\text { Phosphorus, } \\
\text { unfiltered }\end{array}$ & $\begin{array}{l}\text { milligrams per } \\
\text { liter as } \mathrm{P}\end{array}$ & 0.004 & 14 & 3 & 21.4 & $0.004-0.007$ & 0.03 & $0.015-0.371$ & 17.8 \\
\hline
\end{tabular}


The occurrences of high RPDs were isolated and not representative of the dataset as a whole. Acid neutralizing capacity, bicarbonate, ammonia, and suspended sediment each had a single replicate set with an RPD greater than 25 percent. The RPDs for acid neutralizing capacity and bicarbonate were 26.9 and 26.6, respectively. These values were from the same sample, which was collected in December 2014, and the equipment may not have equilibrated to the cold water temperatures. The RPDs greater than 25 percent for acid neutralizing capacity and bicarbonate appear to be an isolated occurrence.

Large RPD values are common and accepted without further discussion when they result from small absolute differences near the constituent censoring level. For example, one ammonia replicate set had an RPD of 66.7; however, the absolute concentration difference was $0.01 \mathrm{mg} / \mathrm{L}$, and the censoring level was $0.01 \mathrm{mg} / \mathrm{L}$. The RPD of 66.7 is also high because of the rounding method used. If unrounded values for ammonia were used for computations, the RPD would be 21.0 percent, which is below the 25 percent threshold.

When the absolute concentration difference is greater than or equal to three times the censoring level and is associated with a large RPD, high variability is indicated. Only one of the replicate pairs for suspended sediment met these criteria, with an RPD of 46.2 percent and an absolute difference of $3 \mathrm{mg} / \mathrm{L}$. The large absolute difference appears to be a random occurrence. Unfiltered constituents are often difficult to replicate because much of the suspended sediment is associated with particles which are not homogenously distributed in the water. Overall, suspended sediment generally showed acceptable reproducibility, but replicate sets will continue to be closely monitored. In general, results for replicate pairs indicated acceptable reproducibility for all water-quality constituents measured during water years 2014 and 2015.

\section{Streamflow}

Streamflow data collected at all 10 TAWSMP gaging stations were reviewed, quality assured, and published as print-ready water year summaries for water years 2014 and 2015 (https://wdr.water.usgs.gov/). Detailed data and summary statistics also are available online through the USGS NWISWeb database (U.S. Geological Survey, 2017; https://doi.org/10.5066/F7P55KJN). For simplicity, streamflow is summarized below in terms of annual runoff compared with the long-term mean for each station's period of record. It is noteworthy that the period of record varies among sites (table 1). At some sites, including New Hope Creek near Blands (site 12), Northeast Creek near Genlee (site 13), and Morgan Creek near Chapel Hill (site 16), a significant percentage of the instream flow consists of treated effluent from municipal water reclamation facilities. These continuous inputs contribute to higher instream flows and tend to mitigate the effects of drought on annual runoff.
Streamflow in water year 2014 was near or above the long-term mean at all gaging stations, with annual runoff values ranging from 10.64 to 32.56 inches (fig. $2 A$ ). In water year 2015, streamflow was below the long-term mean at eight gaging stations, but slightly above the long-term mean at Northeast Creek near Genlee (site 13) and White Oak Creek (site 19). Annual runoff in water year 2015 ranged from 7.25 to 21.75 inches among the 10 gaging stations (fig. $2 B$ ). White Oak Creek (site 19) had periods of zero flow during water years 2014 and 2015; Cane Creek near Orange Grove (site 8) and Morgan Creek near White Cross (site 14) had periods of zero flow during water year 2015. (fig. 2).

\section{Water Quality}

Water-quality data were reviewed and quality assured. The data are presented in appendix 1 and also are available online in Cain and others (2017; https://doi.org/10.5066/ F75X274X). Ranges of concentrations observed at each
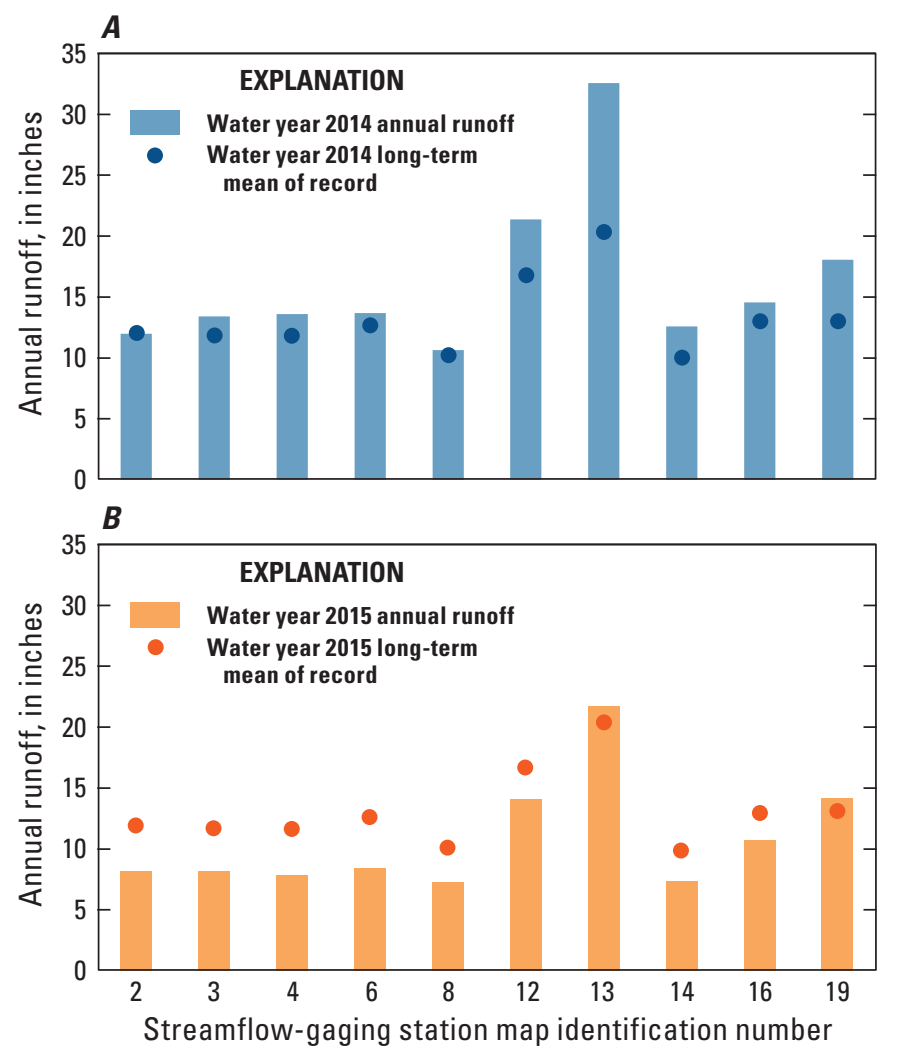

Figure 2. Graphs showing annual runoff measured from $(A)$ October 2013 through September 2014 (water year 2014) and (B) October 2014 through September 2015 (water year 2015), and the long-term mean runoff for the period of record at 10 streamflowgaging stations in the Triangle area of North Carolina. Map identification numbers and the periods of record, which vary among stations, are given in table 1 . 
site for 29 properties or constituents are presented (table 4). Dissolved-oxygen percent saturation, hardness, and total nitrogen were computed by using USGS National Water Information System (NWIS) algorithms. Although the lake sites were sampled at multiple depths, only results from near-surface waters are included in this report. Additional data for lake samples collected in near-bottom waters may be obtained from the USGS NWISWeb database (U.S. Geological Survey, 2017; https://doi.org/10.5066/F7P55KJN) or by request from the USGS South Atlantic Water Science Center (https://www.usgs.gov/water/southatlantic/).

Instream water-quality thresholds have been adopted by the North Carolina Division of Water Quality for 11 constituents monitored by the TAWSMP (table 4). All project sampling sites are classified for water-supply use; therefore, applicable standards are the most stringent values established to protect freshwater aquatic life, water supply, or human health (North Carolina Department of Environmental Quality, 2016). During 2014-15, State water-quality thresholds were 1,000 micrograms per liter $(\mu \mathrm{g} / \mathrm{L})$ for total recoverable iron and $200 \mu \mathrm{g} / \mathrm{L}$ for total recoverable manganese. Subsequently, the U.S. Environmental Protection Agency approved NCDWR's request to remove these thresholds (U.S. Environmental Protection Agency, 2016a); therefore, these thresholds were omitted from table 4. Individual observations that do not meet water-quality thresholds do not constitute violations of the standards nor indicate that the body of water is impaired; however, the thresholds are useful for comparative purposes.

Maximum contaminant levels (MCLs) and National Secondary Drinking Water Regulations (SDWRs) have been established by the U.S. Environmental Protection Agency for five of the monitored constituents (U.S. Environmental Protection Agency, 2016b). These criteria are applicable only to treated potable water - not to raw water supplies - and are provided solely for reference.

Concentration ranges that are shown in table 4 in bold font indicate that at least one sample for the constituent exceeded a North Carolina water-quality threshold at that location. Exceedances of water-quality thresholds occurred at 13 of the 15 sites for at least one constituent. No exceedances of any State water-quality threshold occurred at West Fork Eno Reservoir (site 1) and Little River Reservoir (site 5). Values exceeded thresholds for five water-quality constituents: dissolved oxygen, dissolved-oxygen percent saturation, $\mathrm{pH}$, turbidity, and chlorophyll $a$ (table 4; fig. 3 ). No exceedances of State water-quality thresholds were observed for six constituents: temperature, hardness, chloride, fluoride, sulfate, and nitrate plus nitrite (table 4). 

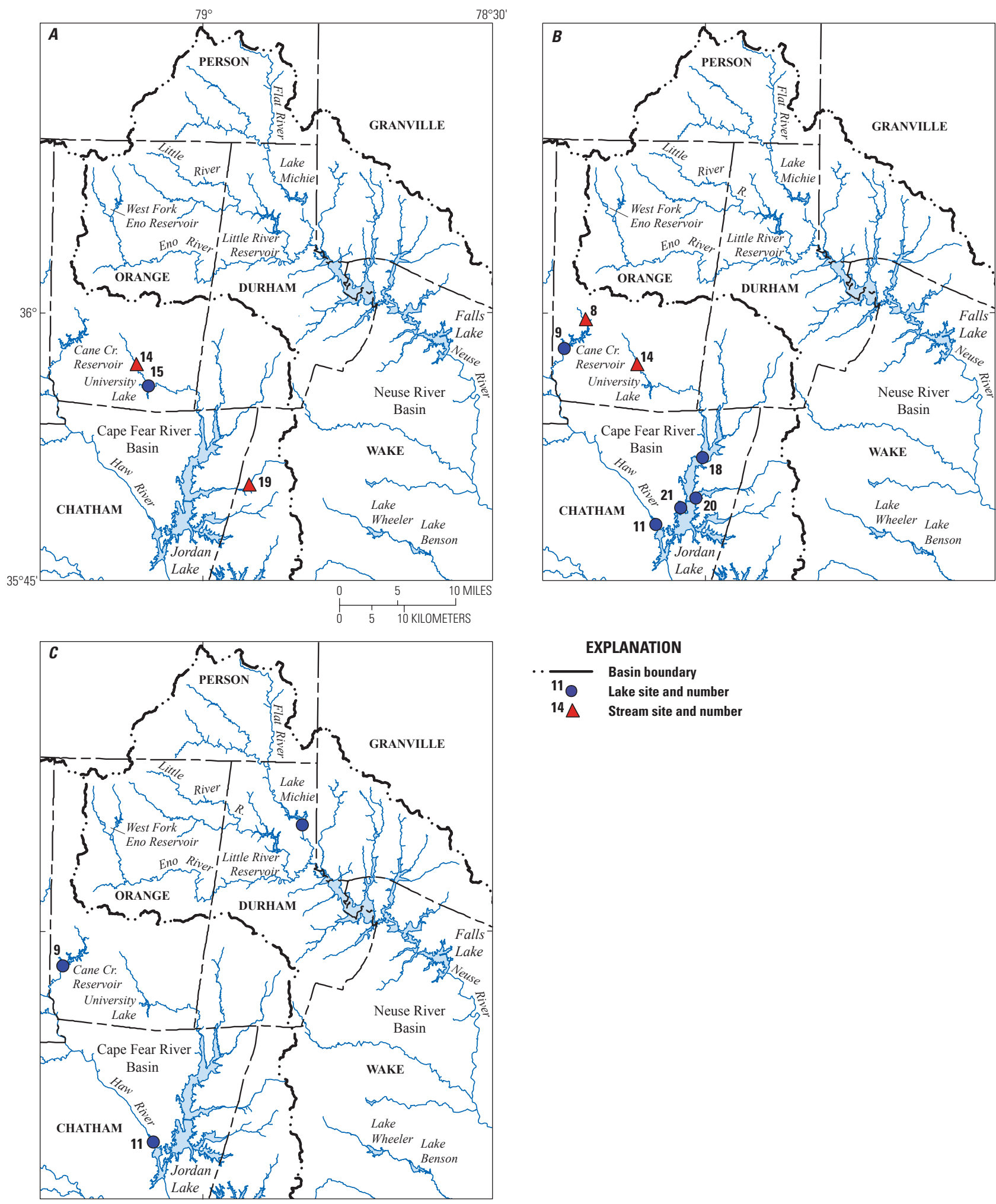

Base from digital files of:

U.S. Environmental Protection Agency, River File 3

U.S. Geological Survey, 1:100,000 scale

Figure 3. Maps showing sites in the Triangle area of North Carolina with one or more measurement of $(A)$ dissolved-oxygen concentration less than 5 milligrams per liter, $(B)$ dissolved-oxygen percent saturation values greater than $110 \mathrm{percent},(C) \mathrm{pH}$ values greater than 9 standard units, $(D)$ turbidity values greater than 25 nephelometric turbidity units for lakes and reservoirs or greater than 50 nephelometric turbidity units for streams, and $(E)$ concentrations of chlorophyll a greater than 40 micrograms per liter, October 2013 through September 2015. (Site information is provided in table 1.) 


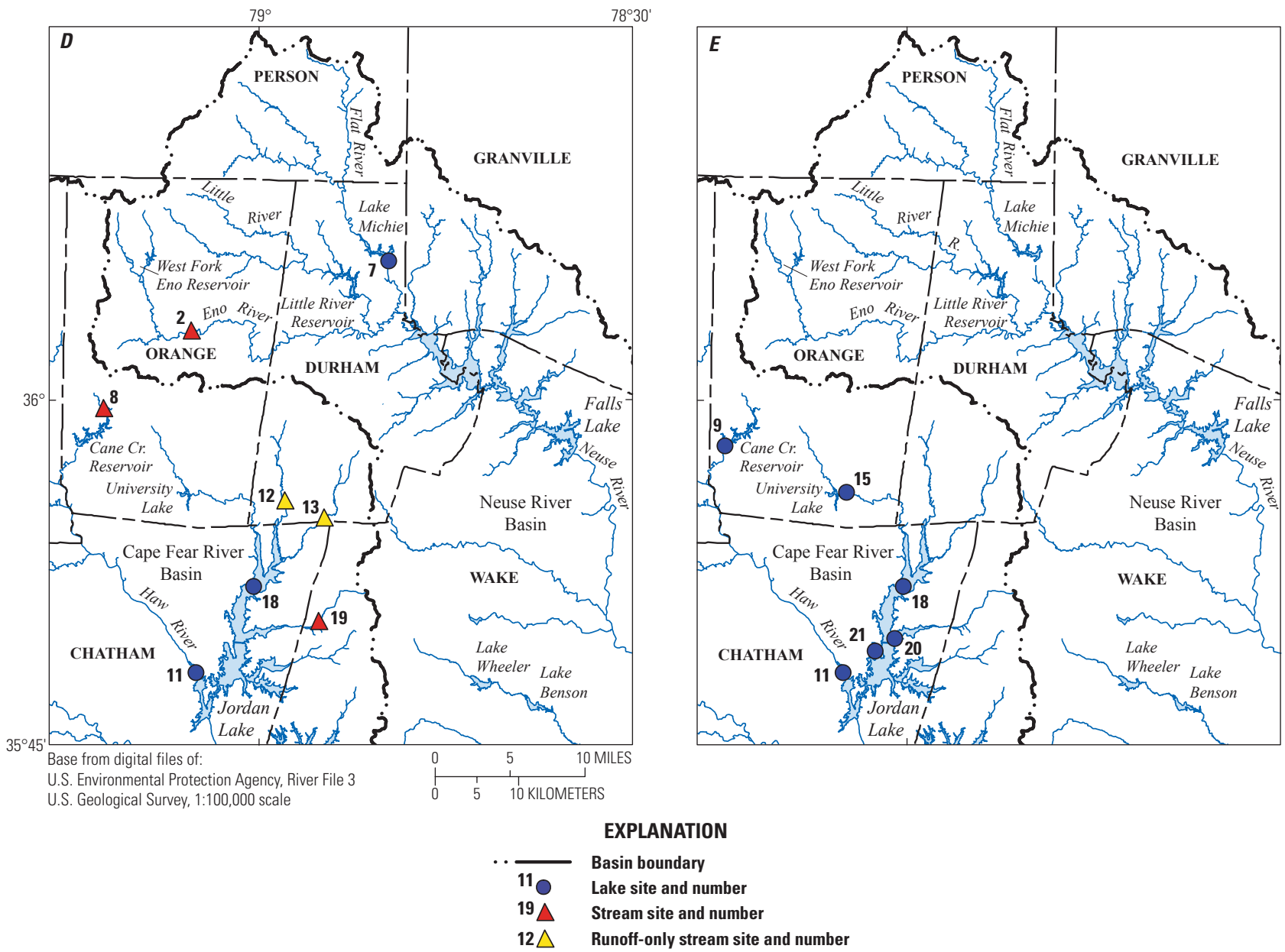

Figure 3. Maps showing sites in the Triangle area of North Carolina with one or more measurement of $(A)$ dissolved-oxygen concentration less than 5 milligrams per liter, $(B)$ dissolved-oxygen percent saturation values greater than 110 percent, $(C) \mathrm{pH}$ values greater than 9 standard units, $(D)$ turbidity values greater than 25 nephelometric turbidity units for lakes and reservoirs or greater than 50 nephelometric turbidity units for streams, and $(E)$ concentrations of chlorophyll a greater than 40 micrograms per liter, October 2013 through September 2015. (Site information is provided in table 1.) —Continued

\section{Summary}

From October 2013 through September 2015, more than 5,500 individual measurements of water quality were made at 15 sites, and continuous records of streamflow were collected at 10 gaging stations in the Triangle Area Water Supply Monitoring Network. Streamflow was generally near or above normal during water year 2014 and below normal during water year 2015. State water-quality thresholds exist for 11 of the 30 constituents measured. These thresholds were exceeded one or more times for dissolved oxygen, dissolved-oxygen percent saturation, $\mathrm{pH}$, turbidity, and chlorophyll $a$. No samples exceeded thresholds for temperature, hardness, chloride, fluoride, sulfate, and nitrate plus nitrite. Approximately 16 percent of the sample load consisted of quality-control samples. Overall, 9 percent of the blank results exceeded censoring levels. The 20 blank detections were distributed among 7 different constituents. Two parameters - ammonia and phosphoruswere present at concentrations that could positively bias the environmental samples. Also, approximately 98 percent of replicate pairs had relative percent differences less than 25 percent. Only one replicate pair-suspended sedimentindicated high variability and will continue to be monitored.

\section{References Cited}

American Society for Testing and Materials, 2002, Method D3977-97, Standard test methods for determining sediment concentration in water samples: West Conshohocken, Pa., ASTM International.

Cain, J.L., Pfeifle, C.A., and Rasmussen, R.B., 2017, Associated data for surface-water supplies in the Triangle area of North Carolina, water years 2014-15: U.S. Geological Survey data release, accessed June 12, 2017, at https://doi.org/10.5066/F75X274X. 
Clesceri, L.S., Greenberg, A.E., and Eaton, A.D., 1998a, Method 5310B, High temperature combustion, Standard methods for the examination of water and wastewater (20th ed.): Washington, D.C., American Public Health Association, American Water Works Association, and Water Environment Federation.

Clesceri, L.S., Greenberg, A.E., and Eaton, A.D., 1998b, Method 3120, Metals in water by plasma emission spectroscopy, Standard methods for the examination of water and wastewater (20th ed.): Washington, D.C., American Public Health Association, American Water Works Association, and Water Environment Federation.

Fishman, M.J., ed., 1993, Methods of analysis by the U.S. Geological Survey National Water Quality LaboratoryDetermination of inorganic and organic constituents in water and fluvial sediments: U.S. Geological Survey Open-File Report 93-125, 217 p.

Fishman, M.J., and Friedman, L.C., eds., 1989, Methods for determination of inorganic substances in water and fluvial sediments: U.S. Geological Survey Techniques of WaterResources Investigations, book 5, chap. A1, 545 p.

Garbarino, J.R., and Struzeski, T.M., 1998, Methods of analysis by the U.S. Geological Survey National Water Quality Laboratory-Determination of elements in wholewater digests using inductively coupled plasma-optical emission spectrometry and inductively coupled plasmamass spectrometry: U.S. Geological Survey Open-File Report 98-165, $101 \mathrm{p}$.

Hambrook Berkman, J.A., and Canova, M.G., 2007, Algal biomass indicators (ver. 1.0): U.S. Geological Survey Techniques of Water-Resources Investigations, book 9 , chap. A7, sec. 7.4, August 2007, accessed September 17, 2015, at https://pubs.water.usgs.gov/twri9A7/.

North Carolina Department of Environmental Quality, 2016, Surface Water Standards, NC Surface Water Quality Standards Tables: North Carolina Division of Water Resources, accessed July 28, 2016, at http://deq.nc.gov/ about/divisions/water-resources/planning/classificationstandards/surface-water-standards\#WQSTables.

Oblinger, C.J., 2004, Triangle Area Supply Monitoring Project, October 1988 through September 2001, North CarolinaDescription of the water-quality network, sampling and analysis methods, and quality-assurance practices: U.S. Geological Survey Open-File Report 2004-1278, 56 p.

Patton, C. J., and Kryskalla, J. R., 2011, Colorimetric determination of nitrate plus nitrite in water by enzymatic reduction, automated discrete analyzer methods: U.S. Geological Survey Techniques and Methods, book 5, chap. B8.
Patton, C.J., and Truitt, E.P., 2000, Methods of analysis by the U.S. Geological Survey National Water Quality Laboratory-Determination of ammonium plus organic nitrogen by a Kjeldahl digestion methods and an automated photometric finish that includes digest cleanup by gas diffusion: U.S. geological Survey Open-File Report 00-170, $31 \mathrm{p}$.

Radtke, D.B., Davis, J.V., and Wilde, F.D., 2005, Specific conductance (ver. 1.2): U.S. Geological Survey Techniques of Water-Resources Investigations, book 9, chap. A6, sec. 6.3, August 2005, accessed September 17, 2015, at https://pubs.water.usgs.gov/twri9A6/.

Ritz, G.F., and Collins, J.A., 2008, pH (ver. 2.0): U.S. Geological Survey Techniques of Water-Resources Investigations, book 9, chap. A6, sec. 6.4, October 2008, accessed September 17, 2015, at https://pubs.water.usgs.gov/twri9A6/.

Rounds, S.A., 2012, Alkalinity and acid neutralizing capacity (ver. 4.0): U.S. Geological Survey Techniques of Water-Resources Investigations, book 9, chap. A6, sec. 6.6, September 2013, accessed September 17, 2015, at https://pubs.water.usgs.gov/twri9A7/.

Rounds, S.A., Wilde, F.D., and Ritz, G.F., 2013, Dissolved oxygen (ver. 3.0): U.S. Geological Survey Techniques of Water-Resources Investigations, book 9, chap. A6, sec. 6.2, September 2013, accessed September 17, 2015, at https://pubs.water.usgs.gov/twri9A6/.

U.S. Environmental Protection Agency, 1993, Method 365.1, Determination of phosphorus by semi-automated colorimetry, revision 2.0: Cincinnati, Ohio, U.S. Environmental Protection Agency, Environmental Monitoring Systems Laboratory, Office of Research and Development, 17 p.

U.S. Environmental Protection Agency, 2016a, Decision Document of the United States Environmental Protection Agency Review of North Carolina's 2007-2015 Triennial Review of Changes to Surface Waters and Wetlands Standards 15A NCAC 02B .0200 Under Section 303(c) of the Clean Water Act: U.S. Environmental Protection Agency, accessed July 28, 2016, at http:/ncdenr.s3.amazonaws.com/ s3fs-public/documents/files/ResponseLetter.pdf.

U.S. Environmental Protection Agency, 2016b, Secondary Drinking Water Standards, Guidance for Nuisance Chemicals: U.S. Environmental Protection Agency web page, accessed August 22, 2016, at https://www.epa. gov/dwstandardsregulations/secondary-drinking-waterstandards-guidance-nuisance-chemicals.

U.S. Geological Survey, 2006, Collection of water samples (ver. 2.0): U.S. Geological Survey Techniques of WaterResources Investigations, book 9, chap. A4, September 2006, accessed March 19, 2014, at https://pubs.water.usgs.gov/ twri9A4/. 
U.S. Geological Survey, 2017, USGS water data for the Nation: U.S. Geological Survey National Water Information System database, assessed January 31, 2017, at https://doi.org/10.5066/F7P55KJN.
Wilde, F.D, 2006, Temperature (ver. 2.0): U.S. Geological Survey Techniques of Water-Resources Investigations, book 9, chap. A6, sec. 6.1, March 2006, accessed September 17, 2015, at https://pubs.water.usgs.gov/twri9A6/. 
Manuscript was approved June 1, 2017

For more information about this publication contact:

Director, South Atlantic Water Science Center

U.S. Geological Survey

720 Gracern Road

Stephenson Center, Suite 129

Columbia, SC 29210

Or visit the South Atlantic Water Science Center website at https://www.usgs.gov/water/southatlantic/.

Prepared by the USGS Science Publishing Network, Reston Publishing Service Center

Edited by Kay Naugle

Illustrations by Jeffrey Corbett

Layout by Cathy Knutson 


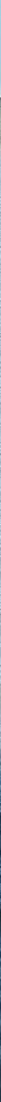

